\title{
Article \\ Characterization of a Novel Aspartic Protease from Rhizomucor miehei Expressed in Aspergillus niger and Its Application in Production of ACE-Inhibitory Peptides
}

\author{
Shounan Wang ${ }^{1 \oplus}$, Peng Zhang ${ }^{2}$, Yibin Xue ${ }^{1}$, Qiaojuan Yan ${ }^{2, *}$, Xue $\mathrm{Li}^{2}$ and Zhengqiang Jiang ${ }^{1, *}$ \\ 1 Department of Nutrition and Health, College of Food Science and Nutritional Engineering, \\ China Agricultural University, Beijing 100083, China; wshounan@cau.edu.cn (S.W.); \\ b20193060539@cau.edu.cn (Y.X.) \\ 2 Key Laboratory of Food Bioengineering (China National Light Industry), College of Engineering, \\ China Agricultural University, Beijing 100083, China; zp2016@cau.edu.cn (P.Z.); lixuel@cau.edu.cn (X.L.) \\ * Correspondence: yanqj@cau.edu.cn (Q.Y.); zhqjiang@cau.edu.cn (Z.J.); \\ Tel.: +86-10-6273-7689 (Z.J.); Fax: +86-10-8238-8508 (Z.J.)
}

check for updates

Citation: Wang, S.; Zhang, P.; Xue, Y.; Yan, Q.; Li, X.; Jiang, Z.

Characterization of a Novel Aspartic

Protease from Rhizomucor miehei

Expressed in Aspergillus niger and Its Application in Production of

ACE-Inhibitory Peptides. Foods 2021, 10, 2949. https://doi.org/10.3390/ foods10122949

Academic Editor: Rotimi Aluko

Received: 26 October 2021

Accepted: 22 November 2021

Published: 30 November 2021

Publisher's Note: MDPI stays neutral with regard to jurisdictional claims in published maps and institutional affiliations.

Copyright: (c) 2021 by the authors. Licensee MDPI, Basel, Switzerland. This article is an open access article distributed under the terms and conditions of the Creative Commons Attribution (CC BY) license (https:// creativecommons.org/licenses/by/ $4.0 /)$.
Abstract: Rhizomucor miehei is an important fungus that produces aspartic proteases suitable for cheese processing. In this study, a novel aspartic protease gene (RmproB) was cloned from R. miehei CAU432 and expressed in Aspergillus niger. The amino acid sequence of RmproB shared the highest identity of $58.2 \%$ with the saccharopepsin PEP4 from Saccharomyces cerevisiae. High protease activity of $1242.2 \mathrm{U} / \mathrm{mL}$ was obtained through high density fermentation in $5 \mathrm{~L}$ fermentor. RmproB showed the optimal activity at $\mathrm{pH} 2.5$ and $40{ }^{\circ} \mathrm{C}$, respectively. It was stable within $\mathrm{pH} 1.5-6.5$ and up to $45^{\circ} \mathrm{C}$. RmproB exhibited broad substrate specificity and had $K_{\mathrm{m}}$ values of $3.16,5.88,5.43$, and $1.56 \mathrm{mg} / \mathrm{mL}$ for casein, hemoglobin, myoglobin, and bovine serum albumin, respectively. RmproB also showed remarkable milk-clotting activity of $3894.1 \mathrm{SU} / \mathrm{mg}$ and identified the cleavage of Lys21-Ile22, Leu32Ser33, Lys63-Pro64, Leu79-Ser80, Phe105-Met106, and Asp148-Ser149 bonds in K-casein. Moreover, duck hemoglobin was hydrolyzed by RmproB to prepare angiotensin-I-converting enzyme (ACE) inhibitory peptides with high ACE-inhibitory activity ( $\mathrm{IC}_{50}$ of $0.195 \mathrm{mg} / \mathrm{mL}$ ). The duck hemoglobin peptides were further produced at kilo-scale with a yield of $62.5 \%$. High-level expression and favorable biochemical characterization of RmproB make it a promising candidate for cheese processing and production of ACE-inhibitory peptides.

Keywords: aspartic protease; milk-clotting; Rhizomucor miehei; Aspergillus niger; ACE-inhibitory peptides

\section{Introduction}

Proteases can hydrolyze proteins through the cleavage of peptide bonds, thus having an important position in industrial enzymes [1]. Aspartic proteases (EC 3.4.23.X) are a class of proteases with an optimal activity in acidic environments and have wide industrial applications, particularly for food and feed $[2,3]$. Chymosin is a type of neonatal gastric aspartic proteases. The chymosin from calf stomach has been used to produce various cheeses [4]. It is the best milk coagulant owing to the high hydrolysis specificity against $\mathrm{K}$-casein at the position of Phe105-Met106 [5]. With the increase of cheese consumption, the demand for chymosin is rapidly rising. Many studies have focused on novel proteases as substitutes for bovine chymosin [1]. Microbial proteases are devoted as one of the promising substitutes for the bovine chymosin [6]. Especially the milk-clotting proteases from Rhizomucor miehei, R. pusillus and Mucor mucedo have widely been applied in the industries [7-9]. Meanwhile, novel proteases from these fungi and efficient expression have potential application for cheese production.

Genetic engineering technology is a promising approach to discover and produce novel proteases. Aspergillus niger has been demonstrated as an important host that produces various proteins based on its high protein secretion efficiency, the ability of complex 
post-translational modifications, and excellent safety $[10,11]$. As a non-pathogenic microorganism, most $A$. niger strains' cultures do not contain mycotoxin and are classified into GRAS (Generally Recognized As Safe) by FDA [12]. Advances in eukaryotic genetic technologies have promoted to express various proteins in A. niger. Many attempts have been contributed to hyperexpress bovine chymosin in $A$. niger through multiple strategies $[13,14]$. The secretion of bovine chymosin in $A$. niger was improved by fusion expression with glucoamylase gene (glaA) [15]. Nitrosoguanidine (NTG) mutagenesis and robotic screening program were performed to increase the production of recombinant bovine chymosin [16]. Another approach was to improve the N-glycosylation site of the prochymosin. Compared with the native chymosin, the yield of highly glycosylated chymosin was increased by more than $100 \%$ [17]. To date, the recombinant bovine chymosin produced by A. niger var. awamori has been commercially used in cheese industry [4]. However, the expression efficiency of heterologous proteins is still restricted by the protein degradation, inefficient transcription, incorrect protein folding, and the difficulty in controlling of mycelial morphology during fermentation, thus hampering the efficient utilization of A. niger [18,19]. So far, no reports have been studied on the expression of Rhizomucor spp. proteases in A. niger.

Bioactive peptides are short amino-acid sequences with different biological properties, which have a positive effect on human health. Peptides derived from food proteins with angiotensin-I-converting enzyme (ACE) inhibitory activity are considered as natural supplements to regulate blood pressure without side effects [20]. Protease hydrolysis is commonly used method to prepare ACE-inhibitory peptides from food proteins. At present, the production of antihypertensive hydrolysates using commercial proteases has been abundantly investigated [21]. The application of novel proteases to prepare bioactive peptides will attract more attention.

R. miehei is an important fungus that has produced multiple proteases and lipases [22,23]. In the previous study, we have heterologously expressed an aspartic protease (RmproA) from R. miehei in P. pastoris [24]. RmproA showed potential application for preparation of turtle peptides and meat tenderization. In this study, to explore more proteases suitable for the food industry, a novel aspartic protease (RmproB) from R.miehei was heterologously expressed in A. niger. Moreover, RmproB was purified and its biochemical properties were characterized, as well as the potential applications for milk-clotting and production of ACE-inhibitory peptides.

\section{Materials and Methods}

\subsection{Strains, Culture Media, and Reagents}

R. miehei CAU432 has been deposited in the China General Microbiological Culture Collection Center (CGMCC No. 4967) with the whole genome sequenced [24]. Escherichia coli Trans5 $\alpha$ (Transgene, Beijing, China) was used for molecular cloning. A. niger strain FBL-A $(\triangle g l a A)$ was used for expression of the protease. It was cultured in Czapek-Dox medium. If necessary, $200 \mu \mathrm{g} / \mathrm{mL}$ hygromycin was added for the hygB selection marker. Casein, hemoglobin, gelatin, whey protein, lactoglobulin, bovine serum albumin, myoglobin, egg albumin, protamine sulfate, collagen, phenylmethylsulfonyl fluoride (PMSF), and pepstatin A were obtained from Sigma-Aldrich Corporation (Darmstadt, Germany). Other chemicals used in this study were provided by Biodee Corporation (Beijing, China).

\subsection{Bioinformatics Analysis and Construction of the Recombinant Plasmid}

Multiple amino acid sequence alignment of RmproB was used by CLUSTALW (https://www.genome.jp/tools-bin/clustalw, accessed on 20 April 2021). The gene of RmproB (GenBank: MZ547666) was PCR amplified from cDNA of R. miehei CAU432. To increase the secretion capacity of RmproB, its signal peptide was replaced by the signal peptide of glucoamylase (glaA) from A. niger. The putative signal peptide sequence of RmproB was predicted by the SignalP 5.0 (http:/ /www.cbs.dtu.dk/services/SignalP/, accessed on 10 May 2021). The A. niger glucoamylase promoter $\mathrm{P}_{g l a A}$ and terminator $\mathrm{T}_{g l a A}$ 
gene were PCR amplified with genomic DNA of $A$. niger FBL-A. The protease expression cassette $\mathrm{P}_{g l a A}-R m p r o B-\mathrm{T}_{t r p C}$ and hygromycin B resistance gene cassette $\mathrm{P}_{g p d a}-h y g B-\mathrm{T}_{\text {gla } A}$ were assembled using the ClonExpress MultiS One Step Cloning Kit (Vazyme, Nanjing, China) and cloned into pEASY-Blunt cloning vector (TransGen, Beijing, China) to construct the expression plasmid pRmproB. All primers were listed in Supplementary Table S1.

\subsection{Transformation and Screening of the Recombinant A. niger}

The $A$. niger strain and linearized plasmid $\mathrm{pRmproB}$ were transformed using the protoplast transformation method with $200 \mu \mathrm{g} / \mathrm{mL}$ hygromycin for selection [25]. The transformants were subcultivated on CD (Czapek-Dox medium) agar plates and confirmed by PCR analysis and sequencing. Positive transformants with correct gene insertion were subjected to shake flask fermentation.

\subsection{Expression and Production of RmproB}

The medium and fermentation conditions used for recombinant protein expression were described by Cai et al. [26]. The transformants were inoculated in $50 \mathrm{~mL}$ fermentation medium under shaking at $250 \mathrm{rpm}$ for 5 days. The culture medium was centrifuged at $10,000 \mathrm{~g}\left(4^{\circ} \mathrm{C}\right.$ and $\left.15 \mathrm{~min}\right)$ to collect crude enzyme. The transformant with the highest protease activity was used to high density fermentation.

High density fermentation was performed in BIOTECH-5BG fermentor (Bxbio, China) which contained $3 \mathrm{~L}$ fermentation medium comprising corn starch hydrolysate $(4 \%, w / v)$, peptone $(2 \%, w / v)$, yeast extract $(1 \%, w / v)$, and $\mathrm{KH}_{2} \mathrm{PO}_{4}(0.5 \%, w / v)$. The $\mathrm{pH}$ was adjusted to $\mathrm{pH} 6.0$ with $28.0 \%$ aqueous ammonia and $10 \%$ phosphoric acid. The fermentation of recombinant $A$. niger consisted of two stages: The first stage was the hyphal growth phase with the agitation rate and temperature kept at $300 \mathrm{rpm}$ and $30^{\circ} \mathrm{C}$, respectively. With the growth of mycelium, the dissolved oxygen (DO) decreased continuously. When the starch hydrolysate in the fermentation medium was completely consumed (about $60-72 \mathrm{~h}$ ), the first stage was ended. For the second stage of enzyme production phase, corn starch hydrolysate $(50 \%, w / v)$ was fed into initial fermentation volume at $5 \mathrm{~mL} / \mathrm{h} / \mathrm{L}$. The DO was kept above $5 \%$ by controlling the agitation rate and air flow until the end of fermentation. During the fermentation process, the wet cell weight, protein concentration, and protease activity were monitored.

\subsection{Measurement of Protease Activity and Protein Content}

The Folin-phenol method previously described by Anson was applied for protease activity measurement [27]. Casein was dissolved in lactate buffer (50 $\mathrm{mM}$ and $\mathrm{pH} 2.5)$ at $1.0 \%(w / v)$ and used as substrate. One unit $(\mathrm{U})$ of protease activity was defined as the amount of protease that is needed for substrate hydrolysis and releasing of $1 \mu \mathrm{g}$ tyrosine per minute. The standard curve of tyrosine was exhibited in Supplementary Figure S1. The Lowry method was used to determine the protein concentration with bovine serum albumin (Sigma, Darmstadt, Germany) as the standard [28].

\subsection{Purification of RmproB}

The crude enzyme was dialyzed overnight in $20 \mathrm{mM}$ sodium phosphate buffer (PBS, pH 6.0). The dialysate was collected and purified using Q-Sepharose Fast Flow column that pre-equilibrated with PBS. PBS containing $\mathrm{NaCl}$ concentration of $0-500 \mathrm{mM}$ was used as the eluent and the enzyme was eluted at $1 \mathrm{~mL} / \mathrm{min}$. The fraction with the protease activity was concentrated and further separated through gel-filtration using Sephacryl-100 column $(1.0 \times 100 \mathrm{~cm})$. PBS was used to elute the protease at $0.3 \mathrm{~mL} / \mathrm{min}$. The purity of protease was analyzed by SDS-PAGE.

\subsection{Biochemical Properties of RmproB}

The optimal $\mathrm{pH}$ of $\mathrm{RmproB}$ for activity was investigated at $40{ }^{\circ} \mathrm{C}$ using $1.0 \%(w / v)$ casein as the substrate in $50 \mathrm{mM}$ different buffers. The buffers used were $\mathrm{KCl}-\mathrm{HCl}(\mathrm{pH} 1.0-$ 
2.0), lactate ( $\mathrm{pH} 2.0-4.0)$, citrate ( $\mathrm{pH} 3.5-6.5)$, phosphate ( $\mathrm{pH} 6.5-8.0)$, and Tris- $\mathrm{HCl}(\mathrm{pH} 8.0-$ 9.0). To determine the $\mathrm{pH}$ stability, the enzyme was pre-incubated in various $\mathrm{pH}$ buffers at $40{ }^{\circ} \mathrm{C}$ for $30 \mathrm{~min}$. The residual protease activity was measured by the standard assay using $1 \%$ casein as a substrate. The optimal temperature of RmproB was determined at temperatures ranging from $20^{\circ} \mathrm{C}$ to $60^{\circ} \mathrm{C}$ in $50 \mathrm{mM}$ lactate buffer ( $\mathrm{pH}$ 2.5). Thermostability was investigated by assessing the residual protease activity after pre-incubation at $25-60{ }^{\circ} \mathrm{C}$ for $30 \mathrm{~min}$.

Effects of metal ions and chemical reagents on the protease activity of RmproB were tested. After incubation with $50 \mathrm{mM}$ lactate buffer ( $\mathrm{pH} 2.5$ ) containing $1 \mathrm{mM} \mathrm{K}^{+}$, $\mathrm{Na}^{+}, \mathrm{Ag}^{+}, \mathrm{Zn}^{2+}, \mathrm{Mg}^{2+}, \mathrm{Fe}^{2+}, \mathrm{Ca}^{2+}, \mathrm{Ni}^{2+}, \mathrm{Cu}^{2+}, \mathrm{Co}^{2+}, \mathrm{Cr}^{2+}, \mathrm{Mn}^{2+}, \mathrm{Ba}^{2+}, \mathrm{Fe}^{3+}, \mathrm{SDS}$, or $\beta-$ mercaptoethanol at $40{ }^{\circ} \mathrm{C}$ for $30 \mathrm{~min}$, the residual protease activity of RmproB was measured with casein $(1 \%, w / v)$ as the substrate. Protease inhibitors of pepstatin A (aspartic protease inhibitor, $0.01 \mathrm{mM}$ and $0.05 \mathrm{mM}$ ), iodoacetamide (cysteine protease inhibitor, $1.0 \mathrm{mM}$ and $5.0 \mathrm{mM}$ ), PMSF (serine protease inhibitor, $1.0 \mathrm{mM}$ and $5.0 \mathrm{mM}$ ), and EDTA (metalloprotease inhibitor, $1.0 \mathrm{mM}$ and $5.0 \mathrm{mM}$ ) were selected and their effects on protease activity of RmproB were determined.

\subsection{Substrate Specificity and Kinetic Parameters of RmproB}

The substrate specificity of RmproB was determined using casein, hemoglobin, collagen, skimmed milk, whey protein, lactoglobulin, bovine serum albumin, myoglobin, egg albumin, protamine sulfate, soy protein isolate, or gelatin as the substrate. The protease activity was assayed in $50 \mathrm{mM}$ lactate buffer ( $\mathrm{pH}$ 2.5) containing $10 \mathrm{mg} / \mathrm{mL}$ of each substrate and kept at $40{ }^{\circ} \mathrm{C}$ for $10 \mathrm{~min}$. The specific activity was measured by the protease activity per mg protein.

The kinetic parameters of RmproB for casein, hemoglobin, myoglobin, and bovine serum albumin were measured in $50 \mathrm{mM}$ lactate buffer $(\mathrm{pH} 2.5)$ at $40{ }^{\circ} \mathrm{C}$ for $5 \mathrm{~min}$. $K_{\mathrm{m}}$ and $V_{\max }$ values were calculated using the software GraFit.

\subsection{Analysis of Milk-Clotting Activity and Casein Hydrolysis of RmproB}

Milk-clotting activity of RmproB was measured according to the previously reported method with minor modifications [29]. Skim milk powder $(10.0 \%, w / v)$ was dissolved in PBS ( $50 \mathrm{Mm}, \mathrm{pH} 4.0$ ) containing $5 \mathrm{mM} \mathrm{CaCl}_{2}$ and used as the substrate. Then, aliquots of the substrate $(5 \mathrm{~mL})$ were mixed with the RmproB solution $(0.5 \mathrm{~mL})$ and kept at $37^{\circ} \mathrm{C}$ under manual rotation. The clotting time was recorded after coagulation was observed. The milk-clotting activity (Soxhlet units, SU) was defined as the amount of enzyme needed to clot $1 \mathrm{~mL}$ substrate in $40 \mathrm{~min}$ at $37^{\circ} \mathrm{C}$.

The effects of $\mathrm{pH}$ and $\mathrm{CaCl}_{2}$ on the milk-clotting activity of $\mathrm{RmproB}$ were investigated. RmproB was added to the $10 \%$ skim milk powder in citrate buffer within $\mathrm{pH}$ 3.5-6.5. The milk-clotting activity of RmproB at $\mathrm{pH} 4.0$ was taken as $100 \%$. The milk-clotting index viz. the ratio of milk-clotting activity to protease activity (CA/PA) was calculated. The effects of $\mathrm{CaCl}_{2}$ on milk-clotting activity of $\mathrm{RmproB}$ were evaluated using $10 \%$ skim milk powder in citrate buffer ( $\mathrm{pH}$ 4.0) containing different $\mathrm{CaCl}_{2}$ concentrations. The milkclotting activity at $5 \mathrm{mM} \mathrm{CaCl}_{2}$ was taken as $100 \%$.

To analyze the casein hydrolysis by RmproB, commercial bovine caseins of $\alpha_{S^{-}}, \beta-$, and $\mathrm{k}$-casein $(1.0 \%, w / v)$ were dissolved in $50 \mathrm{mM}$ citrate buffer $(\mathrm{pH} 4.0)$ and mixed with RmproB (10 SU/mL). The reaction was kept at $40{ }^{\circ} \mathrm{C}$ and samples were taken at time intervals of $0,5,10$, and $30 \mathrm{~min}$. After enzyme deactivation through boiling for $5 \mathrm{~min}$, hydrolysates of casein were analyzed by SDS-PAGE. The cleavage sites of RmproB in $\mathrm{k}$ casein were analyzed by MALDI-TOF MS (matrix-assisted laser desorption ionization-time of flight mass spectrometry). Peptide sequence retrieval of $\mathrm{k}$-casein hydrolysates was conducted using MASCOT (http:/ / www.matrixscience.com, accessed on 20 June 2021) as previously described [30]. 


\subsection{Preparation of ACE-Inhibitory Peptides by RmproB}

The duck hemoglobin $(10 \%, w / v)$ was suspended in $50 \mathrm{mM}$ lactate buffer ( $\mathrm{pH} 2.5)$. RmproB (50 U/mL) was added and hydrolyzed at $40{ }^{\circ} \mathrm{C}$ for $0,2,4,6$, and $8 \mathrm{~h}$. Then, the suspension was boiled for $5 \mathrm{~min}$ to deactivate the enzyme. After centrifugation at $10,000 \times g$ for $10 \mathrm{~min}$, the supernatants were analyzed for the molecular weight distribution and the ACE-inhibitory activity.

Molecular weight distributions of the duck hemoglobin and hydrolysates were analyzed by HPLC (high-performance liquid chromatography) system using the method described by Zhang et al. [31]. In short, the mobile phase was deionized water, acetonitrile, and trichloroacetic acid with a ratio of 55:45:0.1. The suspension of $5 \mathrm{mg} / \mathrm{mL}$ duck hemoglobin or the lyophilized hydrolysates was filtered and injected into an Agilent 1260 HPLC system with TSKgel-G2000SWXL column $(7.8 \times 300 \mathrm{~mm})$. The flow rate was $0.5 \mathrm{~mL} / \mathrm{min}$, and the absorbance was set on $214 \mathrm{~nm}$. Nine standard proteins (glycine-tyrosine, valine-tyrosine-valine, cytochrome $\mathrm{C}$, apomyoglobin, ribonuclease $\mathrm{A}$, holo-transferrin, angiotensin II, leucine encephalin, and methionine enkephalin) were used to plot the calibration curves of molecular weight. The chromatogram was divided into four areas with different molecular weight $(<1 \mathrm{kDa}, 1-2 \mathrm{kDa}, 2-5 \mathrm{kDa}$, and $>5 \mathrm{kDa})$. The molecular weight distribution of the peptide fractions was determined as the percentage of the total area.

The ACE-inhibitory activity of duck hemoglobin peptides with different hydrolysis times was using the previously reported method [32]. The ACE-inhibitory activity (\%) was calculated based on the following equation:

$$
\text { ACE }- \text { inhibitory activity }(\%)=\frac{\text { Absorbance of control }- \text { Absorbance of sample }}{\text { Absorbance of control }- \text { Absorbance of blank }} \times 100 \%
$$

The duck hemoglobin peptides were further produced at the kilo-scale in an agitated reactor (YHL-20L, Yuhua, Zhucheng, China). The duck hemoglobin $(10 \%, w / v)$ suspended with $10 \mathrm{~L}$ pure water was added in the reactor. The $\mathrm{pH}$ was adjusted to $\mathrm{pH} 2.5$ with $\mathrm{HCl}$. RmproB $(50 \mathrm{U} / \mathrm{mL})$ was added and the hydrolysis process was kept at $40{ }^{\circ} \mathrm{C}$ with a stirring rate of $200 \mathrm{rpm}$. After enzymatic hydrolysis for $8 \mathrm{~h}$, the hydrolysate was conducted using a plate filter (WBG-1, Hundong, Guangzhou, China) with a $0.45 \mu \mathrm{m}$ filter cloth $(300 \mathrm{~mm}$ ) for the solid-liquid separation. The liquid fraction was concentrated by vacuum rotary evaporation (R-1050, Ensheng, Shanghai, China) and then spray-dried by spray dryer (PGL-B, Changzhoujiafa, Jiangsu, China).

\section{Results}

\subsection{Gene Cloning and Sequence Analysis of RmproB}

An aspartic protease gene (RmproB) from $R$. miehei was cloned. The ORF (open reading frame) of the gene (RmproB) was $1779 \mathrm{bp}$ containing five introns (228 bp, $69 \mathrm{bp}, 60 \mathrm{bp}$, $56 \mathrm{bp}$, and $46 \mathrm{bp}$ ) and encoded a protein of 439 amino acids with a predicted signal peptide of 19 amino acids. The gene sequence was submitted into the GenBank database under the accession number MZ547666.

According to the multiple amino acid sequence alignments (Figure 1), RmproB showed the highest amino acid sequence identity of $58.2 \%$ with the saccharopepsin PEP4 from Saccharomyces cerevisiae (P07267.1) [33], followed by the aspartic proteinase PEP2 from A. fumigatus (50.1\%, O42630.1) [34], and the vacuolar protease A from Neurospora crassa (47.9\%, Q01294.2) [35]. Especially, it shared very low amino acid sequence identity of 18.9\% with RmproA from R. miehei (ATY35192.1) [24]. Asp106 and Asp291 in RmproB were the putative conversed catalytic residues. 


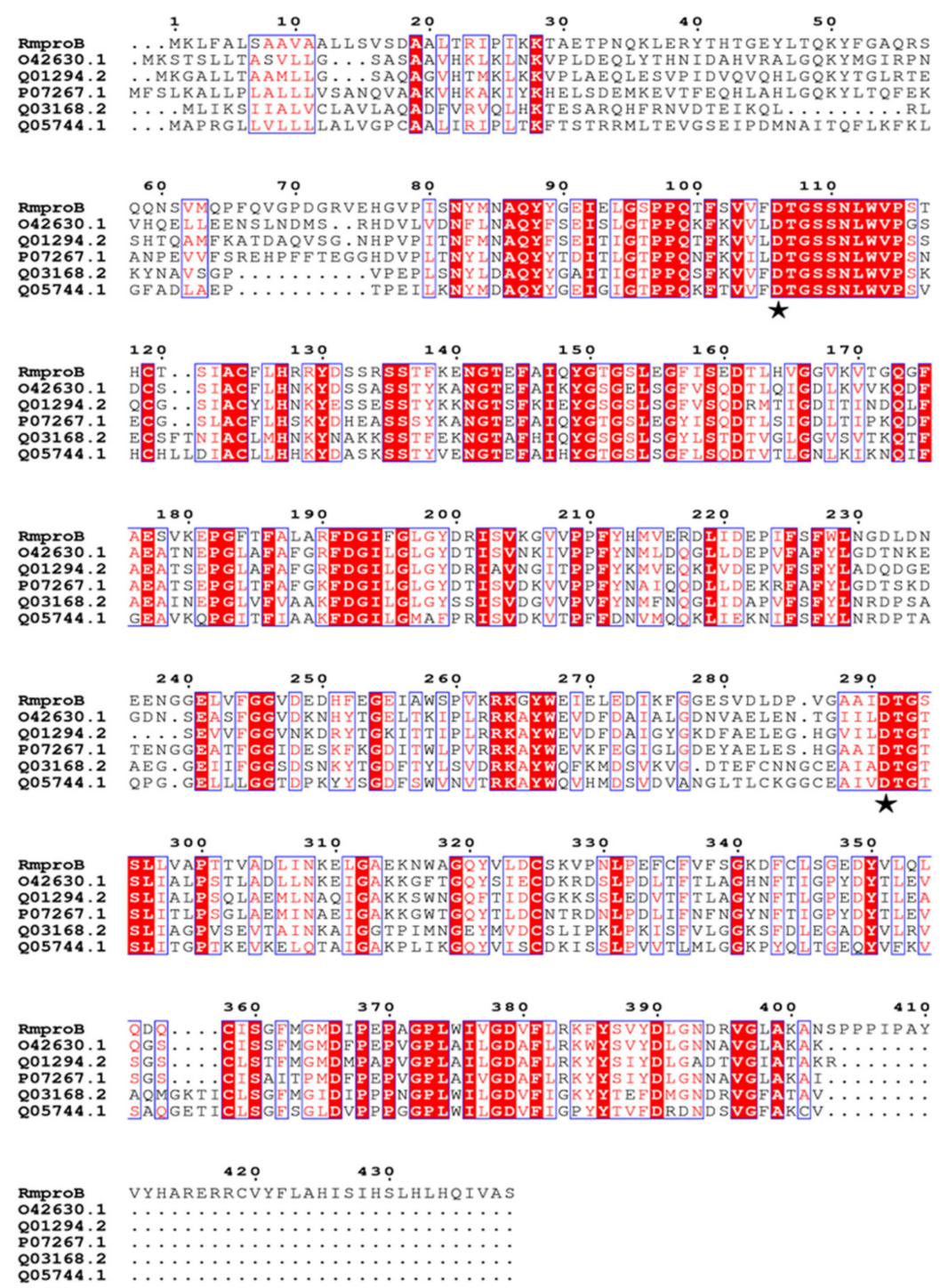

Figure 1. Multiple amino acid sequence alignment of RmproB with other A1 family aspartic proteases. RmproB was the aspartic protease from R. miehei in this study. The sequences, O42630.1 (Aspergillus fumigatus), Q01294.2 (Neurospora crassa), P07267.1 (Saccharomyces cerevisiae), Q03168.2 (Aedes aegypti), and Q05744.1 (Gallus gallus) were downloaded from the NCBI protein database. Identical residues are shaded in red, and conserved residues are shown in blue boxes. The conversed catalytic residues are marked with asterisks.

\subsection{Expression and Purification of RmproB}

RmproB was expressed under the control of promoter $\mathrm{P}_{\text {glaA }}$ and secreted into the medium owing to the glucoamylase signal peptide. The protease was successfully expressed as the main extracellular protein in the fermentation broth. The highest protease activity of $1242.2 \mathrm{U} / \mathrm{mL}$ with protein concentration of $6.1 \mathrm{mg} / \mathrm{mL}$ was produced after incubation for $168 \mathrm{~h}$ in $5 \mathrm{~L}$ fermenter (Figure 2A). 


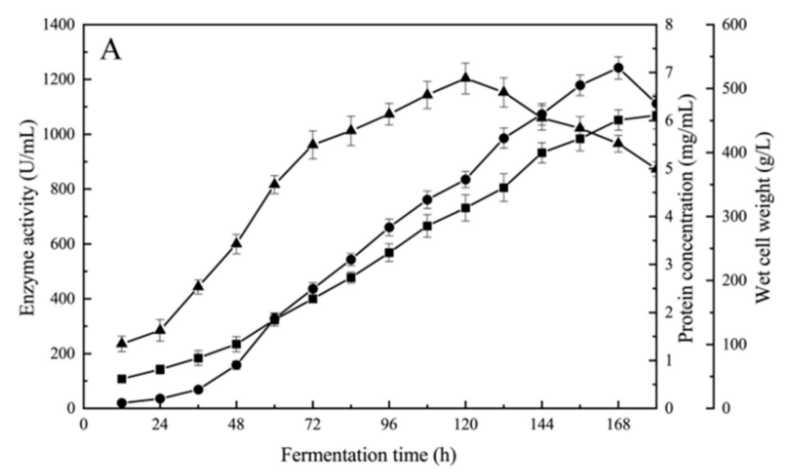

B $\mathrm{kDa}$

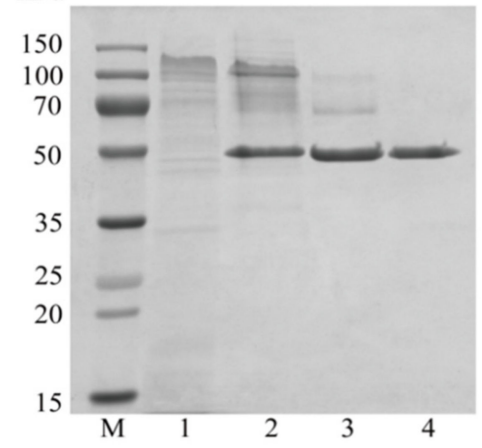

Figure 2. Time-course of RmproB produced by A. niger in $5 \mathrm{~L}$ fermentor (A) and SDS-PAGE analysis of the purified RmproB (B). Symbols are enzyme activity $(\bullet)$, protein concentration $(\boldsymbol{\square})$, and wet cell weight $(\mathbf{\Delta})$ of high-density fermentation (A). Lane M, protein molecular weight marker; lane 1, A. niger FBL-A for control; lane 2, the crude supernatant; lane 3, RmproB after QSFF; lane 4, RmproB after S-100 (B).

After Q-Sepharose chromatography and Sephacryl-100 gel filtration chromatography, RmproB was purified 3.9 folds to apparent homogeneity with a recovery yield of $18.8 \%$. The purified RmproB exhibited specific activity of 3176.1 U/mg (Supplementary Table S2). The molecular weight of purified RmproB was estimated to be $49.4 \mathrm{kDa}$ with a single band in SDS-PAGE (Figure 2B).

\subsection{Biochemical Characterization of RmproB}

The optimal pH of RmproB was pH 2.5 in lactate buffer (Figure 3A). The protease exhibited high stability within an acid $\mathrm{pH}$ range of 1.5-6.5 (activity above $80 \%$ ), and 99.1\% residual activity was retained after incubation at $\mathrm{pH} 1.5$ for $30 \mathrm{~min}$ (Figure $3 \mathrm{~A}$ ). RmproB showed optimal activity at $40{ }^{\circ} \mathrm{C}$ and was stable up to $45^{\circ} \mathrm{C}$ for $30 \mathrm{~min}$, maintaining around $83 \%$ residual activity (Figure $3 \mathrm{~B}$ ). 
A

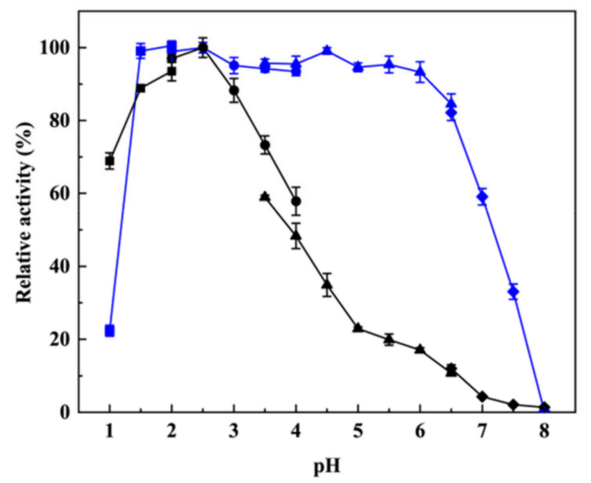

B

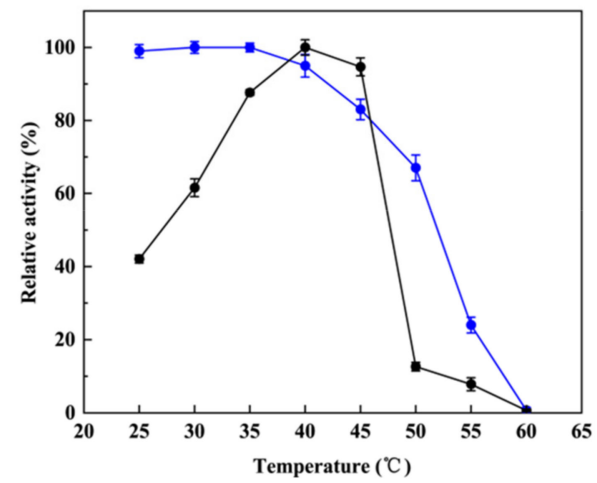

Figure 3. Optimal $\mathrm{pH}$ (A, black polyline) and $\mathrm{pH}$ stability (A, blue polyline) of RmproB, optimal temperature (B, black polyline) and thermostability (B, blue polyline) of RmproB. The optimal $\mathrm{pH}$ of RmproB was determined in $50 \mathrm{mM}$ various buffers at $40^{\circ} \mathrm{C}$. The buffers used are $\mathrm{KCl}-\mathrm{HCl}(\boldsymbol{\square}$,

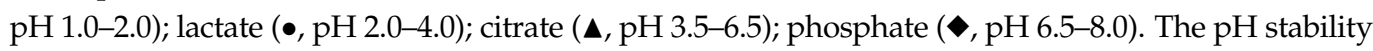
was assessed by measuring the residual protease activity after the enzyme was pre-incubated at $40{ }^{\circ} \mathrm{C}$ for $30 \mathrm{~min}$ in buffers mentioned above. The optimal temperature was tested in $50 \mathrm{mM}$ lactate buffer ( $\mathrm{pH}$ 2.5) at different temperatures $\left(20-60^{\circ} \mathrm{C}\right)$. The thermostability was evaluated by investigating the residual protease activity after pre-incubation in $50 \mathrm{mM}$ lactate buffer $(\mathrm{pH} 2.5)$ at $25-60{ }^{\circ} \mathrm{C}$ for $30 \mathrm{~min}$.

The protease activity of RmproB was activated by $\mathrm{Mn}^{2+}(120.5 \%)$ and strongly inhibited by SDS (4.4\%). The other chemicals exhibited no or slight effects on the protease activity of RmproB. The enzyme activity of RmproB was completely inhibited by $0.05 \mathrm{mM}$ pepstatin A, suggesting that RmproB is an aspartic protease (Supplementary Table S3). Protease inhibitors of PMSF, EDTA, and iodoacetamide had no significant effects on the protease activity of RmproB, indicating that the serine residue, metal ions, or - $\mathrm{SH}$ group had no effect on the protease activity of RmproB.

The purified RmproB showed broad substrate specificity towards the tested substrates (Table 1). RmproB exhibited the highest protease activity towards casein $(100.0 \%)$, followed by hemoglobin $(94.8 \%)$, myoglobin $(80.4 \%)$, bovine serum albumin $(73.8 \%)$, and skimmed milk (60.4\%). However, it did not exhibit any detectable activity towards soy protein isolate, gelatin, protamine sulfate, and collagen.

Table 1. Substrate Specific Activities of RmproB ${ }^{1}$.

\begin{tabular}{ccc}
\hline Substrate & Specific Activity $(\mathbf{U} / \mathbf{m g})^{\mathbf{2}}$ & Relative Activity (\%) \\
\hline Casein & $3176.1 \pm 67.1$ & 100 \\
Hemoglobin & $3011.1 \pm 78.2$ & $94.8 \pm 2.5$ \\
Myoglobin & $2552.3 \pm 68.8$ & $80.4 \pm 2.2$ \\
Bovine serum albumin & $2344.3 \pm 79.7$ & $73.8 \pm 2.5$ \\
Skimmed milk & $1917.1 \pm 84.7$ & $60.4 \pm 2.7$ \\
Egg albumin & $1393.5 \pm 17.0$ & $43.9 \pm 0.5$ \\
Whey protein & $631.3 \pm 81.0$ & $19.9 \pm 2.5$ \\
Lactoglobulin & $161.9 \pm 148.2$ & $5.1 \pm 4.7$ \\
\hline
\end{tabular}

${ }_{1}^{1}$ Specific activities are shown as mean \pm SD $(n=3)$. The enzyme activity towards casein is defined as $100 \%$. ${ }^{2}$ Specific activities of RmproB towards the substrates were tested by the protease activity per mg protein. One unit $(\mathrm{U})$ of hydrolytic activity was defined by the amount of protease that hydrolyzed substrate to release $1 \mu \mathrm{g}$ tyrosine per minute.

The kinetic parameters of RmproB for casein, hemoglobin, myoglobin, and bovine serum albumin were determined. The $K_{\mathrm{m}}$ and $V_{\max }$ values of RmproB were $3.16 \mathrm{mg} / \mathrm{mL}$ and $3583 \mu \mathrm{mol} / \mathrm{min} / \mathrm{mg}$ for casein, $5.88 \mathrm{mg} / \mathrm{mL}$ and $4572 \mu \mathrm{mol} / \mathrm{min} / \mathrm{mg}$ for hemoglobin, $5.43 \mathrm{mg} / \mathrm{mL}$ and $3623 \mu \mathrm{mol} / \mathrm{min} / \mathrm{mg}$ for myoglobin, and $1.56 \mathrm{mg} / \mathrm{mL}$ and $1732 \mu \mathrm{mol} / \mathrm{min} / \mathrm{mg}$ for bovine serum albumin. 


\subsection{Milk-Clotting Activity and Casein Hydrolysis}

The milk-clotting activity of crude enzyme was measured to be $1285.7 \mathrm{SU} / \mathrm{mL}$. After purification, RmproB exhibited high milk-clotting activity of $3894.1 \mathrm{SU} / \mathrm{mg}$. It showed the optimal milk-clotting activity at $\mathrm{pH} 4.0$ and $5 \mathrm{mM} \mathrm{CaCl}_{2}$ (Supplementary Figure S2). Under the optimal conditions, RmproB exhibited the milk-clotting index (CA/PA) of 6.1.

Multiple caseins were hydrolyzed by RmproB. The protease exhibited various hydrolysis patterns towards three different components of casein. SDS-PAGE analysis revealed that RmproB showed higher hydrolysis ability against $k$-casein than those of $\alpha_{\mathrm{s}}$-casein and $\beta$-casein (Figure 4). After incubation for $5 \mathrm{~min}$, $\mathrm{k}$-casein was hydrolyzed into two major peptide fragments with molecular weight of $8 \mathrm{kDa}$ and $10 \mathrm{kDa}$. In contrast, $\alpha_{\mathrm{s}}$-casein was randomly and partially hydrolyzed into small fragments with molecular weights of 18-30 kDa. $\beta$-Casein was only degraded into two major peptide fragments with molecular weight of $8 \mathrm{kDa}$ and $15 \mathrm{kDa}$. Based on the peptides from $\mathrm{k}$-casein hydrolyzed by RmproB, Lys21-Ile22, Leu32-Ser33, Lys63-Pro64, Leu79-Ser80, Phe105-Met106, and Asp148-Ser149 bonds in $\mathrm{K}$-casein were identified as the primary cleavage sites (Table 2).

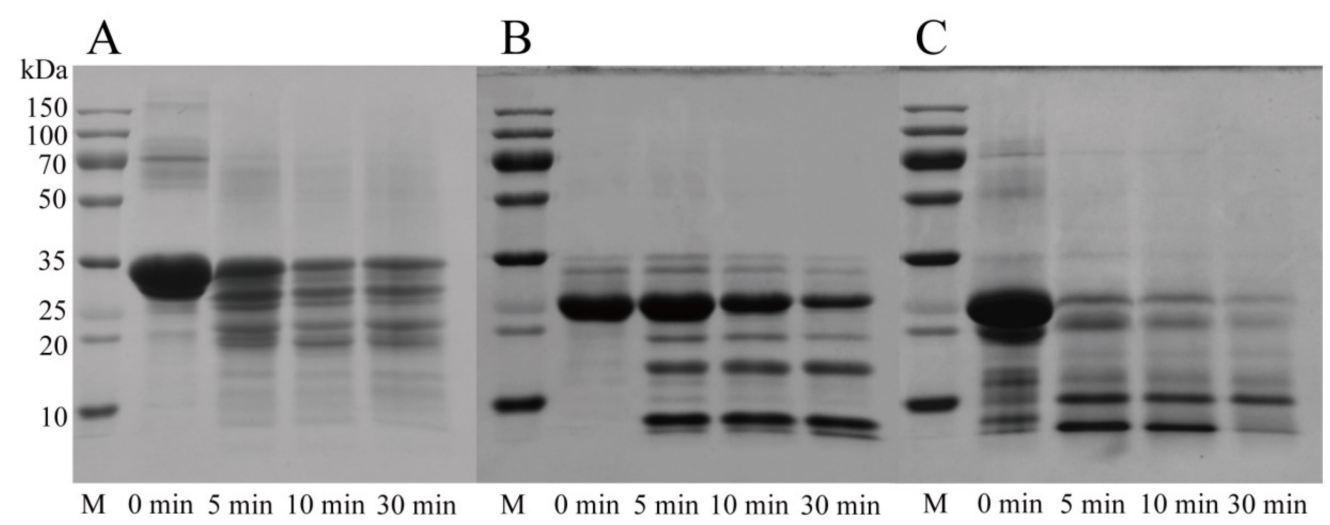

Figure 4. SDS-PAGE analysis of $\alpha_{\mathrm{s}}$-casein (A), $\beta$-casein (B), and $\kappa$-casein (C) hydrolyzed by RmproB. Lane M, protein molecular weight marker; other lanes, three types of caseins hydrolyzed by RmproB (10 SU/mL) in $50 \mathrm{mM} \mathrm{pH} 4.0$ citrate buffer for $0,5,10$, and $30 \mathrm{~min}$.

Table 2. Identity of Peptides Derived from K-Casein Hydrolyzed by RmproB.

\begin{tabular}{|c|c|c|c|}
\hline Start-End & $\operatorname{Mr}(\operatorname{expt})^{1}$ & $\operatorname{Mr}\left(\right.$ calc) ${ }^{2}$ & Peptide Sequences ${ }^{3}$ \\
\hline $22-32$ & 1319.7829 & 1319.7853 & K.IAKYIPIQYVL.S \\
\hline $33-63$ & 3757.8904 & 3757.8932 & L.SRYPSYGLNYYQQKPVALINNQFLPYPYYAK.P \\
\hline $64-79$ & 1776.0013 & 1776.0046 & K.PAAVRSPAQILQWQVUL.S \\
\hline 80-105 & 3012.4690 & 3012.4811 & L.SNTVPAKSCQAQPTTMARHPHPHLSF.M \\
\hline $106-148$ & 4525.2573 & 4525.2633 & F.MAIPPKKNQDKTEIPTINTIASGEPTSTPTTEAVESTVATLED.S \\
\hline $149-169$ & 2196.1274 & 2196.1162 & D.SPEVIESPPEINTVQVTSTAV.- \\
\hline
\end{tabular}

${ }^{1} \mathrm{Mr}$ (expt) means experimental molecular weight. ${ }^{2} \mathrm{Mr}$ (calc) means calculated molecular weight. ${ }^{3}$ MALDI-TOF-MS peptide map of k-casein hydrolyzed by RmproB.

\subsection{Preparation of ACE-Inhibitory Peptides by RmproB}

The potential of RmproB was evaluated to prepare ACE-inhibitory peptides from duck hemoglobin. The molecular weight distribution and ACE-inhibitory activity of the hydrolysates at different hydrolysis intervals were shown in Supplementary Figure S3 and Table 3. With the increase of hydrolysis time, duck hemoglobin was hydrolyzed into smaller peptides $(<1 \mathrm{kDa})$ from the intact molecule $(>5 \mathrm{kDa})$. Small peptides $(<1 \mathrm{kDa})$ were generated at a large amount of $88.5 \%$. After $8 \mathrm{~h}$ hydrolysis, duck hemoglobin peptides showed high ACE-inhibitory activity of $90.7 \%$ at concentration of $0.5 \mathrm{mg} / \mathrm{mL}$. The $\mathrm{IC}_{50}$ value of duck hemoglobin peptides for ACE-inhibitory activity was $0.195 \mathrm{mg} / \mathrm{mL}$. The production of duck hemoglobin peptides was enlarged to kilo-scale, as shown in the flow 
diagram (Figure 5). After the four-step process, $624.7 \mathrm{~g}$ peptides powder was obtained with a product yield of $62.5 \%$.

Table 3. Molecular Weight Distribution and ACE-Inhibitory Activity of the Duck Hemoglobin and Hydrolysates ${ }^{1}$.

\begin{tabular}{cccccc}
\hline \multirow{2}{*}{ Hydrolysis Time (h) } & \multicolumn{3}{c}{ Molecular Weight Distribution (\%) } & \multirow{2}{*}{ ACE-Inhibitory Rate (\%) ${ }^{\mathbf{2}}$} \\
\cline { 2 - 5 } & $\mathbf{<} \mathbf{~ k D a}$ & $\mathbf{1 - 2} \mathbf{~ k D a}$ & $\mathbf{2 - 5} \mathbf{~ k D a}$ & $\mathbf{> 5}_{\mathbf{~ k D a}}$ & \\
\hline 0 & 16.8 & 2.9 & 13.5 & 66.8 & $8.6 \pm 1.2^{\mathrm{a}}$ \\
2 & 71.9 & 13.5 & 10.1 & 4.5 & $71.9 \pm 1.6^{\mathrm{b}}$ \\
4 & 79.8 & 12.0 & 7.3 & 0.9 & $79.2^{\mathrm{b}} \pm 0.2^{\mathrm{c}}$ \\
6 & 84.1 & 10.8 & 5.1 & 0.0 & $85.1 \pm 1.2^{\mathrm{d}}$ \\
8 & 88.5 & 8.9 & 2.6 & 0.0 & $90.7 \pm 1.4^{\mathrm{e}}$ \\
\hline
\end{tabular}

${ }^{1}$ The ACE-inhibitory rate was shown as mean $\pm \mathrm{SD}(\mathrm{n}=3)$. A value of $p<0.05$ was considered statistically significant. ${ }^{2}$ The ACE-inhibitory rate was determined at concentration of $0.5 \mathrm{mg} / \mathrm{mL}$.

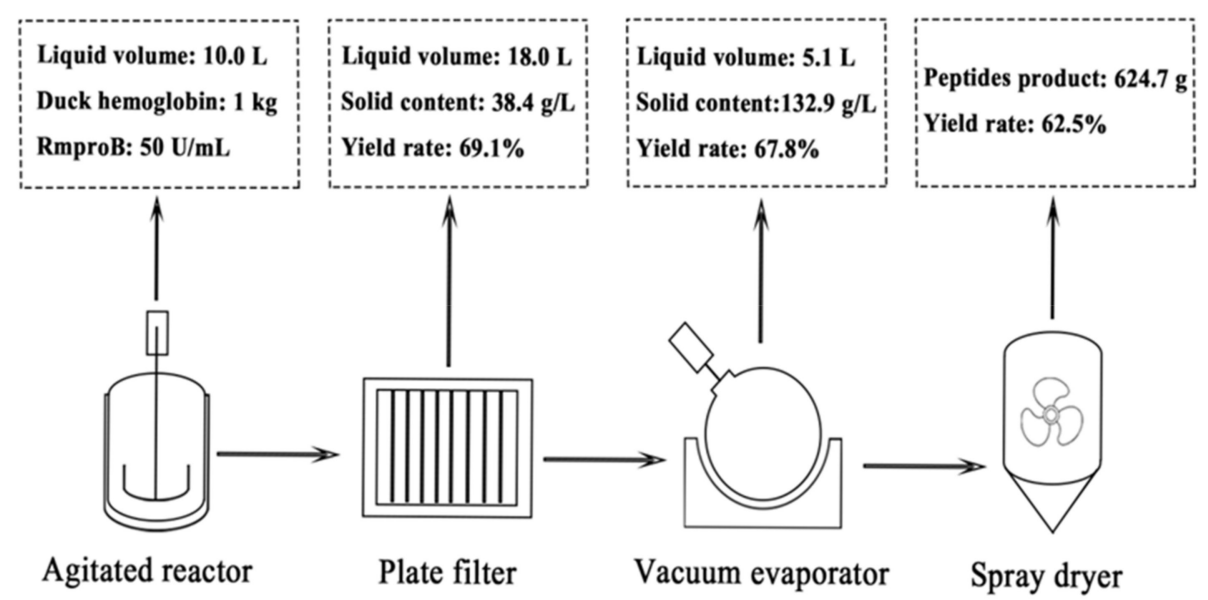

Figure 5. Flow diagram of production of duck hemoglobin peptides at kilo-scale. The solid content was defined as the ratio of the weight of the lyophilized solid to the total solution volume. The yield was defined as the percentage of the weight of the obtained duck hemoglobin peptides to the initial substrate.

\section{Discussion}

Aspartic proteases have a wide range of applications in various food fields, including cheese, bakery, and wine [1]. R. miehei has been reported to produce multiple proteases and lipases for food application, such as cheese processing, meat tenderization, and lipid synthesis [22,23]. Much work has been done to study the wild type aspartic proteases from $R$. miehei to improve the volatile composition and sensory properties of cheese $[23,36]$. In this study, a novel aspartic protease (RmproB) from R. miehei CAU432 was extracellularly expressed in A. niger. RmproB exhibited the highest sequence similarity of $58.2 \%$ with the saccharopepsin PEP4 from S. cerevisiae (Figure 1). Combined with the inhibition by pepstatin A, RmproB should be a new A1 family aspartic protease [33].

Usually, proteins expressed in A. niger are mainly achieved through using organismspecific, endogenous gene expression elements (endogenous transcription factors, signal peptides, promoters, and terminators) [11]. The wild type glucoamylase and amylase secreted by $A$. niger have strong promoters $\mathrm{P}_{\text {glaA }}$ and $\mathrm{P}_{a m y A}$, which are often used to regulate the expression of heterologous proteins [19]. RmproB was expressed under the regulation of the promoter $\mathrm{P}_{g l a A}$ and the glucoamylase signal peptide. The highest protease activity of RmproB (1242.2 $\mathrm{U} / \mathrm{mL}$ ) was produced in $5 \mathrm{~L}$ fermentor (Figure $2 \mathrm{~A}$ ), which is much higher than those microbial aspartic proteases from Trichoderma harzianum $(321.8 \mathrm{U} / \mathrm{mL})$ [37] and Penicillium sp. (89.3 U/mL) [38] expressed in P. pastoris but lower than the acid protease 
from A. kawachii expressed in A. niger (5543 U/mL) [39] and RmproA from R. miehei expressed in P. pastoris (3480.4 U/mL) [24].

The molecular weight of aspartic proteases commonly ranges from 35 to $50 \mathrm{kDa}$ [3]. RmproB had a molecular weight of $49.4 \mathrm{kDa}$ (Figure 2B), which is similar to that of RmproA from $R$. miehei CAU432 (50.6 kDa) [24] and higher than the wild type aspartic proteases from $R$. miehei isolated from decaying wood ( $37 \mathrm{kDa}$ ) [40]. The purified RmproB showed specific activity of $3176.1 \mathrm{U} / \mathrm{mg}$ (Supplementary Table S2), which is much higher than those of the aspartic proteases from Talaromyces leycettanus (1795.4 U/mg) [41] and RmproA (773.3 U/mg) [24]. The optimal pH of RmproB is pH 2.5 (Figure 3A), which is the same as the recombinant aspartic protease from T. harzianum ( $\mathrm{pH}$ 2.5) [37] but lower than the wild type aspartic protease from A. niger ( $\mathrm{pH}$ 3.5) [42], the milk-clotting protease from R. miehei NRRL 3500 (pH 4.1) [43], and the RmproA from R. miehei CAU432 (pH 5.5) [24]. Furthermore, RmproB exhibited the optimal temperature at $40{ }^{\circ} \mathrm{C}$ (Figure $3 \mathrm{~B}$ ), which is higher than the milk-clotting protease from $R$. miehei NRRL $3500\left(35^{\circ} \mathrm{C}\right)$ [43] and lower than the wild type aspartic peptidase from $R$. miehei $\left(55^{\circ} \mathrm{C}\right)$ [40] and the RmproA from R. miehei CAU432 $\left(55^{\circ} \mathrm{C}\right)$ [24]. RmproB lost its activity after incubation at $60^{\circ} \mathrm{C}$ for $30 \mathrm{~min}$ (Figure 3B), indicating the ability for thermal inactivation of RmproB to prevent excessive hydrolysis of substrates. Extensive or unspecific hydrolysis towards caseins may lead to undesirable characteristics of cheese [5]. Thermal inactivation can prevent residual protease during manufacturing and avoid undesirable texture and flavor in the cheese [44]. RmproB exhibited broad substrate specificity towards casein, hemoglobin, myoglobin, and bovine serum albumin, with $K_{\mathrm{m}}$ values of $3.16,5.88,5.43$, and $1.56 \mathrm{mg} / \mathrm{mL}$, respectively. The $K_{\mathrm{m}}$ values of RmproB for different substrates are lower than that of MpAPr1 from the yeast Metschnikowia pulcherrima (5.9 mg/mL towards casein) [45], aspergillopepsin A-like from A. niger ( $6.3 \mathrm{mg} / \mathrm{mL}$ towards hemoglobin) [42], and the aspartic protease from A. oryzae MTCC 5341 (8 mg/mL towards hemoglobin) [46].

RmproB showed high milk-clotting activity of $3894.1 \mathrm{SU} / \mathrm{mg}$, which is similar to the chymosin from Rhizopus microsporus var. rhizopodiformis (3905 SU/mg) [47] and higher than those from A. oryzae MTCC 5341 (3500 SU/mg) [48] and Termitomyces clypeatus MTCC 5091 (150.9 SU/mg) [44]. High milk-clotting activity and low protease activity are ideal properties of proteases being suitable for cheese production [6]. RmproB showed the optimal coagulation activity at $\mathrm{pH} 4.0$ with a high milk-clotting index (CA/PA) of 6.1 (Supplementary Figure S2A). However, the milk-clotting protease from R. miehei NRRL 3500 showed optimal $\mathrm{pH}$ at 5.6 with CA/PA of 2.3 [43]. For commercial bovine chymosin, high concentration of $\mathrm{CaCl}_{2}$ causes an increase in both milk-clotting activity and the total protease activity [4]. RmproB showed the optimal milk-clotting activity at $5 \mathrm{mM} \mathrm{CaCl}_{2}$ concentration (Supplementary Figure S2B), which avoids the growing risk of protease activity due to the addition of calcium ions. The hydrolysis capacity at a specific position in the $\mathrm{K}$ casein is a crucial factor for the assessment of coagulation efficiency. The bovine chymosin specifically cleaves k-casein at Phe105-Met106 residues and releases the C-terminal region of $\mathrm{k}$-casein (caseinomacropeptide), causing a decrease in the colloidal stability of micelles and resulting in milk curdling [6]. RmproB showed a significant degradation of $k$-casein but a relatively weak degradation of $\alpha_{\mathrm{s}}$-casein and $\beta$-casein (Figure 4). Similar properties of milk-clotting proteases have been demonstrated from Bacillus amyloliquefaciens GSBa-1 [49] and T. clypeatus MTCC 5091 [44]. SDS-PAGE exhibited that $\mathrm{k}$-casein was hydrolyzed by RmproB, yielding two major peptide fragments with molecular weights of $8 \mathrm{kDa}$ and $10 \mathrm{kDa}$ (Figure 4). The peptide bonds of Lys21-Ile22, Leu32-Ser33, Lys63-Pro64, Leu79Ser80, Phe105-Met106, and Asp148-Ser149 in K-casein were the primary hydrolysis sites for RmproB (Table 2). The mechanism of milk coagulation for RmproB is similar to the bovine chymosin. The cleavage of Phe105-Met106 bond may be the initial and critical step during coagulation. The other cleavage sites can be attributable to the secondary proteolysis of peptides [44].

Duck meat is consumed in large quantities all over the world, especially in Asia. In 2019, the number of commercial ducks sold was up to 4.3 billion in China [50]. Duck 
blood is one of the main by-products during the slaughter process. As an abundant source of protein, duck blood is considered a non-allergenic protein compared with soy and dairy proteins [51]. Recently, studies have discovered antioxidant peptides from duck blood [51,52]. Food-derived ACE-inhibitory peptides are promising components for the prevention and treatment of hypertension [53]. Turtle meat was hydrolyzed by RmproA to prepare ACE-inhibitory peptides with ACE-inhibitory activity of $88 \%$ at concentration of $1 \mathrm{mg} / \mathrm{mL}$ [24]. In this study, duck hemoglobin hydrolyzed by RmproB showed high ACEinhibitory activity of $90.7 \%$ at concentration of $0.5 \mathrm{mg} / \mathrm{mL}$ (Table 3). The $\mathrm{IC}_{50}$ value of duck hemoglobin peptides for ACE-inhibitory activity was $0.195 \mathrm{mg} / \mathrm{mL}$. Pepsin is the most commonly used commercial aspartic protease in the preparation of bioactive peptides. The globin derived from porcine hemoglobin was digested by pepsin to prepare ACEinhibitory peptides with $\mathrm{IC}_{50}$ of $1.19 \mathrm{mg} / \mathrm{mL}$ [54]. The camel whey hydrolyzed by pepsin displayed ACE-inhibitory activity as $\mathrm{IC}_{50}$ of $0.197 \mathrm{mg} / \mathrm{mL}$ [55]. The pistachio hydrolysates by pepsin and trypsin showed ACE-inhibitory activity as $\mathrm{IC}_{50}$ of $0.87 \mathrm{mg} / \mathrm{mL}$ [56]. In kiloscale production, the yield of duck hemoglobin peptides was up to $62.5 \%$ (Figure 5). The results verified the feasibility of RmproB used for the efficient production of ACEinhibitory peptides from duck hemoglobin.

\section{Conclusions}

A novel A1 family aspartic protease (RmproB) from R. miehei was expressed in A. niger. High protease activity was produced through high density fermentation. RmproB showed remarkable milk-clotting activity with a high CA/PA ratio. Moreover, RmproB was used to produce bioactive peptides from duck hemoglobin. The hydrolysates show excellent ACEinhibitory activity and satisfactory yield. The ability of milk-clotting and bioactive peptides preparation make RmproB a promising candidate for food processing. Future studies will be devoted to applying RmproB to cheese production and investigating the bioactive components of duck hemoglobin peptides.

Supplementary Materials: The following are available online at https:/ /www.mdpi.com/article/ 10.3390/foods10122949/s1, Figure S1: Standard curve of tyrosine. Figure S2: Optimal pH (A) and optimal $\mathrm{CaCl}_{2}$ concentration (B) for MCA (milk-clotting activity) of RmproB. Figure S3: Molecular weight distribution of the duck hemoglobin hydrolysates at different hydrolysis intervals. Table S1: The sequences of all primers used. Table S2: Purification summary of the recombinant protease (RmproB) expressed in A. niger. Table S3: Inhibition of the recombinant protease (RmproB) by various protease inhibitors.

Author Contributions: Investigation, data curation, visualization, writing original draft, S.W.; investigation, formal analysis, P.Z. and Y.X.; software, X.L.; conceptualization, supervision, funding acquisition, writing - review and editing, Q.Y. and Z.J. All authors have read and agreed to the published version of the manuscript.

Funding: This work was supported by the 13th National Five-Year Plan for Key Research and Development of China "Green Biological Manufacturing" (No. 2021YFC2100302).

Data Availability Statement: The gene sequence in this study has been deposited to the NCBI GenBank database under the accession number MZ547666.

Conflicts of Interest: The authors declare no conflict of interest.

\section{References}

1. Gurumallesh, P.; Alagu, K.; Ramakrishnan, B.; Muthusamy, S. A systematic reconsideration on proteases. Int. J. Biol. Macromol. 2019, 128, 254-267. [CrossRef] [PubMed]

2. Razzaq, A.; Shamsi, S.; Ali, A.; Ali, Q.; Sajjad, M.; Malik, A.; Ashraf, M. Microbial Proteases Applications. Front. Bioeng. Biotechnol. 2019, 7, 110. [CrossRef] [PubMed]

3. Theron, L.W.; Divol, B. Microbial aspartic proteases: Current and potential applications in industry. Appl. Microbiol. Biotechnol. 2014, 98, 8853-8868. [CrossRef] [PubMed]

4. Belenkaya, S.V.; Balabova, D.V.; Belov, A.N.; Koval, A.D.; Shcherbakov, D.N.; Elchaninov, V.V. Basic Biochemical Properties of Recombinant Chymosins (Review). Appl. Biochem. Microbiol. 2020, 56, 363-372. [CrossRef] 
5. Dalgleish, D.G.; Corredig, M. The Structure of the Casein Micelle of Milk and Its Changes During Processing. Annu. Rev. Food Sci. Technol. 2012, 3, 449-467. [CrossRef]

6. Da Silva, R.R. Exploring Microbial Peptidases for Cheese Production: A Viewpoint on the Current Conjecture. J. Agric. Food Chem. 2018, 66, 1305-1306. [CrossRef]

7. Leite Júnior, B.R.D.C.; Tribst, A.A.L.; Cristianini, M. Influence of high pressure homogenization on commercial protease from Rhizomucor miehei: Effects on proteolytic and milk-clotting activities. LWT Food Sci. Technol. 2015, 63, 739-744. [CrossRef]

8. Stergiou, P.Y.; Foukis, A.; Gkini, O.A.; Barouni, E.; Georgoulia, P.S.; Kanellaki, M.; Koutinas, A.A.; Papagianni, M.; Papamichael, E.M. Novel FRET-substrates of Rhizomucor pusillus rennin: Activity and mechanistic studies. Food Chem. 2018, 245, 926-933. [CrossRef]

9. Yegin, S.; Goksungur, Y.; Fernandez-Lahore, M. Purification, structural characterization, and technological properties of an aspartyl proteinase from submerged cultures of Mucor mucedo DSM 809. Food Chem. 2012, 133, 1312-1319. [CrossRef]

10. Meyer, V.; Basenko, E.Y.; Benz, J.P.; Braus, G.H.; Caddick, M.X.; Csukai, M.; De Vries, R.P.; Endy, D.; Frisvad, J.C.; Gunde-Cimerman, N.; et al. Growing a circular economy with fungal biotechnology: A white paper. Fungal Biol. Biotechnol. 2020, 7, 5. [CrossRef]

11. Mojzita, D.; Rantasalo, A.; Jäntti, J. Gene expression engineering in fungi. Curr. Opin. Biotechnol. 2019, 59, 141-149. [CrossRef]

12. Schuster, E.; Dunn-Coleman, N.; Frisvad, J.; van Dijck, P. On the safety of Aspergillus niger-A review. Appl. Microbiol. Biotechnol. 2002, 59, 426-435. [CrossRef]

13. Mohanty, A.; Mukhopadhyay, U.; Grover, S.; Batish, V. Bovine chymosin: Production by rDNA technology and application in cheese manufacture. Biotechnol. Adv. 1999, 17, 205-217. [CrossRef]

14. Sharma, R.; Katoch, M.; Srivastava, P.S.; Qazi, G.N. Approaches for refining heterologous protein production in filamentous fungi. World J. Microbiol. Biotechnol. 2009, 25, 2083-2094. [CrossRef]

15. Ward, M.; Wilson, L.J.; Kodama, K.H.; Rey, M.W.; Berka, R.M. Improved Production of Chymosin in Aspergillus by Expression as a Glucoamylase-Chymosin Fusion. Nat. Biotechnol. 1990, 8, 435-440. [CrossRef]

16. Dunn-Coleman, N.S.; Bloebaum, P.; Berka, R.M.; Bodie, E.; Robinson, N.; Armstrong, G.; Ward, M.; Przetak, M.; Carter, G.L.; LaCost, R.; et al. Commercial Levels of Chymosin Production by Aspergillus. Bio/Technology 1991, 9, 976-981. [CrossRef]

17. van den Brink, H.M.; Petersen, S.G.; Rahbek-Nielsen, H.; Hellmuth, K.; Harboe, M. Increased production of chymosin by glycosylation. J. Biotechnol. 2006, 125, 304-310. [CrossRef]

18. Nevalainen, H.; Peterson, R. Making recombinant proteins in filamentous fungi- are we expecting too much? Front. Microbiol. 2014, 5, 75. [CrossRef]

19. Wösten, H.A.B. Filamentous fungi for the production of enzymes, chemicals and materials. Curr. Opin. Biotechnol. 2019, 59, 65-70. [CrossRef]

20. Coronado-Cáceres, L.J.; Hernández-Ledesma, B.; Mojica, L.; Quevedo-Corona, L.; Rabadán-Chávez, G.; Castillo-Herrera, G.A.; Lugo Cervantes, E. Cocoa (Theobroma cacao L.) Seed-Derived Peptides Reduce Blood Pressure by Interacting with the Catalytic Site of the Angiotensin-Converting Enzyme. Foods 2021, 10, 2340. [CrossRef]

21. Xue, L.; Yin, R.; Howell, K.; Zhang, P. Activity and bioavailability of food protein-derived angiotensin-I-converting enzymeinhibitory peptides. Compr. Rev. Food Sci. Food Saf. 2021, 20, 1150-1187. [CrossRef]

22. Han, Z.-L.; Han, S.-Y.; Zheng, S.-P.; Lin, Y. Enhancing thermostability of a Rhizomucor miehei lipase by engineering a disulfide bond and displaying on the yeast cell surface. Appl. Microbiol. Biotechnol. 2009, 85, 117-126. [CrossRef]

23. Soltani, M.; Sahingil, D.; Gokce, Y.; Hayaloglu, A.A. Changes in volatile composition and sensory properties of Iranian ultrafiltered white cheese as affected by blends of Rhizomucor miehei protease or camel chymosin. J. Dairy Sci. 2016, 99, 7744-7754. [CrossRef]

24. Sun, Q.; Chen, F.; Geng, F.; Luo, Y.; Gong, S.; Jiang, Z. A novel aspartic protease from Rhizomucor miehei expressed in Pichia pastoris and its application on meat tenderization and preparation of turtle peptides. Food Chem. 2018, 245, 570-577. [CrossRef]

25. Chen, X.; Wang, B.; Pan, L. Heterologous expression and characterization of Penicillium citrinum nuclease P1 in Aspergillus niger and its application in the production of nucleotides. Protein Expr. Purif. 2019, 156, 36-43. [CrossRef]

26. Cai, L.-N.; Xu, S.-N.; Lu, T.; Lin, D.-Q.; Yao, S.-J. Directed expression of halophilic and acidophilic $\beta$-glucosidases by introducing homologous constitutive expression cassettes in marine Aspergillus niger. J. Biotechnol. 2019, 292, 12-22. [CrossRef]

27. Anson, M.L. The estimation of pepsin, trypsin, papain, and cathepsin with hemoglobin. J. Gen. Physiol. 1938, 22, 79-89. [CrossRef]

28. Lowry, O.H.; Rosebrough, N.J.; Farr, A.L.; Randall, R.J. Protein measurement with the Folin phenol reagent. J. Biol. Chem. 1951, 193, 265-275. [CrossRef]

29. Arima, K.; Iwasaki, S.; Tamura, G. Milk Clotting Enzyme from Microorganisms. Agric. Biol. Chem. 1967, 31, 540-551. [CrossRef]

30. Egito, A.; Girardet, J.-M.; Laguna, L.; Poirson, C.; Mollé, D.; Miclo, L.; Humbert, G.; Gaillard, J.-L. Milk-clotting activity of enzyme extracts from sunflower and albizia seeds and specific hydrolysis of bovine k-casein. Int. Dairy J. 2007, 17, 816-825. [CrossRef]

31. Zhang, P.; Chang, C.; Liu, H.; Li, B.; Yan, Q.; Jiang, Z. Identification of novel angiotensin I-converting enzyme (ACE) inhibitory peptides from wheat gluten hydrolysate by the protease of Pseudomonas aeruginosa. J. Funct. Foods 2020, 65, 103751. [CrossRef]

32. Cushman, D.; Cheung, H. Spectrophotometric assay and properties of the angiotensin-converting enzyme of rabbit lung. Biochem. Pharmacol. 1971, 20, 1637-1648. [CrossRef]

33. Woolford, C.; Daniels, L.B.; Park, F.J.; Jones, E.W.; Van Arsdell, J.N.; A Innis, M. The PEP4 gene encodes an aspartyl protease implicated in the posttranslational regulation of Saccharomyces cerevisiae vacuolar hydrolases. Mol. Cell. Biol. 1986, 6, $2500-2510$. [CrossRef] [PubMed]

34. Reichard, U.; Cole, G.T.; Rüchel, R.; Monod, M. Molecular cloning and targeted deletion of PEP2 which encodes a novel aspartic proteinase from Aspergillus fumigatus. Int. J. Med. Microbiol. 2000, 290, 85-96. [CrossRef] 
35. Vázquez-Laslop, N.; Tenney, K.; Bowman, B.J. Characterization of a Vacuolar Protease in Neurospora crassa and the Use of Gene RIPing to Generate Protease-deficient Strains. J. Biol. Chem. 1996, 271, 21944-21949. [CrossRef]

36. Celebi, M.; Topuzogullari, M.; Kuzu, H. Thermal Destabilization of Rhizomucor miehei Rennet with Aldehyde Dextran Sulfate: Purification, Bioconjugation and Milk-Clotting Activities. Appl. Biochem. Biotechnol. 2016, 180, 261-273. [CrossRef]

37. Deng, J.-J.; Huang, W.-Q.; Li, Z.; Lu, D.-L.; Zhang, Y.; Luo, X.-C. Biocontrol activity of recombinant aspartic protease from Trichoderma harzianum against pathogenic fungi. Enzym. Microb. Technol. 2018, 112, 35-42. [CrossRef]

38. Guo, Y.; Li, X.; Jia, W.; Huang, F.; Liu, Y.; Zhang, C. Characterization of an intracellular aspartic protease (PsAPA) from Penicillium sp. XT7 and its application in collagen extraction. Food Chem. 2021, 345, 128834. [CrossRef]

39. Li, J.; Wu, T.; Ma, N.; Wang, X.; Yang, J.; Li, J.; Zhang, H. Expression of acid protease from Aspergillus kawachii in Aspergillus niger. J. Northeast Agric. Univ. 2016, 47, 29-35. [CrossRef]

40. da Silva, R.R.; Souto, T.B.; de Oliveira, T.B.; de Oliveira, L.C.G.; Karcher, D.; Juliano, M.A.; Juliano, L.; de Oliveira, A.H.C.; Rodrigues, A.; Rosa, J.C.; et al. Evaluation of the catalytic specificity, biochemical properties, and milk clotting abilities of an aspartic peptidase from Rhizomucor miehei. J. Ind. Microbiol. Biotechnol. 2016, 43, 1059-1069. [CrossRef]

41. Guo, Y.; Tu, T.; Yuan, P.; Wang, Y.; Ren, Y.; Yao, B.; Luo, H. High-level expression and characterization of a novel aspartic protease from Talaromyces leycettanus JCM12802 and its potential application in juice clarification. Food Chem. 2019, 281, 197-203. [CrossRef]

42. Purushothaman, K.; Bhat, S.K.; Singh, S.A.; Marathe, G.; Rao, A.R.G.A. Aspartic protease from Aspergillus niger: Molecular characterization and interaction with pepstatin A. Int. J. Biol. Macromol. 2019, 139, 199-212. [CrossRef]

43. Preetha, S.; Boopathy, R. Purification and characterization of a milk clotting protease from Rhizomucor miehei. World J. Microbiol. Biotechnol. 1997, 13, 573-578. [CrossRef]

44. Majumder, R.; Banik, S.P.; Khowala, S. Purification and characterisation of $\mathrm{k}$-casein specific milk-clotting metalloprotease from Termitomyces clypeatus MTCC 5091. Food Chem. 2015, 173, 441-448. [CrossRef]

45. Theron, L.W.; Bely, M.; Divol, B. Characterisation of the enzymatic properties of MpAPr1, an aspartic protease secreted by the wine yeast Metschnikowia pulcherrima. J. Sci. Food Agric. 2017, 97, 3584-3593. [CrossRef]

46. Vishwanatha, K.; Rao, A.G.A.; Singh, S.A. Characterisation of acid protease expressed from Aspergillus oryzae MTCC 5341. Food Chem. 2009, 114, 402-407. [CrossRef]

47. Sun, Q.; Wang, X.-P.; Yan, Q.-J.; Chen, W.; Jiang, Z.-Q. Purification and Characterization of a Chymosin from Rhizopus microsporus var. rhizopodiformis. Appl. Biochem. Biotechnol. 2014, 174, 174-185. [CrossRef]

48. Vishwanatha, K.S.; Rao, A.G.A.; Singh, S.A. Production and characterization of a milk-clotting enzyme from Aspergillus oryzae MTCC 5341. Appl. Microbiol. Biotechnol. 2009, 85, 1849-1859. [CrossRef]

49. Zhao, X.; Cai, M.; Yang, Z.-J.; Luo, T.-Q.; Sarwar, A.; Megrous, S.; Aziz, T.; Yang, Z.-N. Purification and characterization of a novel milk-clotting enzyme produced by Bacillus amyloliquefaciens GSBa-1. Eur. Food Res. Technol. 2019, 245, 2447-2457. [CrossRef]

50. Jin, S.; Pang, Q.; Yang, H.; Diao, X.; Shan, A.; Feng, X. Effects of dietary resveratrol supplementation on the chemical composition, oxidative stability and meat quality of ducks (Anas platyrhynchos). Food Chem. 2021, 363, 130263. [CrossRef]

51. Yang, J.; Huang, J.; Dong, X.; Zhang, Y.; Zhou, X.; Huang, M.; Zhou, G. Purification and identification of antioxidant peptides from duck plasma proteins. Food Chem. 2020, 319, 126534. [CrossRef]

52. Yang, J.; Huang, J.; Zhu, Z.; Huang, M. Investigation of optimal conditions for production of antioxidant peptides from duck blood plasma: Response surface methodology. Poult. Sci. 2020, 99, 7159-7168. [CrossRef]

53. Abadía-García, L.; Castaño-Tostado, E.; Cardador-Martínez, A.; Martín-Del-Campo, S.T.; Amaya-Llano, S.L. Production of ACE Inhibitory Peptides from Whey Proteins Modified by High Intensity Ultrasound Using Bromelain. Foods 2021, 10, 2099. [CrossRef]

54. Yu, Y.; Hu, J.; Bai, X.; Du, Y.; Lin, B. Preparation and function of oligopeptide-enriched hydrolysate from globin by pepsin. Process. Biochem. 2006, 41, 1589-1593. [CrossRef]

55. Baba, W.N.; Baby, B.; Mudgil, P.; Gan, C.-Y.; Vijayan, R.; Maqsood, S. Pepsin generated camel whey protein hydrolysates with potential antihypertensive properties: Identification and molecular docking of antihypertensive peptides. LWT Food Sci. Technol. 2021, 143, 111135. [CrossRef]

56. Li, P.; Jia, J.; Fang, M.; Zhang, L.; Guo, M.; Xie, J.; Xia, Y.; Zhou, L.; Wei, D. In vitro and in vivo ACE inhibitory of pistachio hydrolysates and in silico mechanism of identified peptide binding with ACE. Process. Biochem. 2014, 49, 898-904. [CrossRef] 